\title{
Discovery Learning to Improve Science Learning Achievement of Class VI Elementary Students
}

\section{Titi Ariyanti}

SDN Tepakyang

titiariyan@gmail.com

\section{Article History}

accepted 14/11/2020

approved 21/11/2020

published 26/11/2020

\begin{abstract}
The purposes this research was to determine that the aplication of the discovery learning model can improve the science learning achievement of grade VI elementary school students. The research conducted was Classroom Action Research (CAR) for three cycles, with each cycle consisting of one meeting. The stages of each cycle are planning, observation, observation and reflection. In the first cycle, the students who completed the test reached $60 \%$, in second cycle $80 \%$, and the third cycle $87 \%$. These results indicate that the discovery learning model can improve the learning achievement of students in grade VI science subject matter at SDN Tepakyang.
\end{abstract}

Keywords: discovery learning model, learning achievement, science

\section{Abstrak}

Tujuan dari penelitian ini adalah untuk mengetahui bahwa penerapan model discovery learning dapat meningkatkan prestasi belajar IPA peserta didik kelas VI sekolah dasar. Penelitian yang dilakukan adalah Penelitian Tindakan Kelas (PTK) sebanyak tiga siklus, dengan setiap siklusnya terdiri dari satu pertemuan. Tahapan setiap siklusnya adalah perencanaan, tindakan, observasi dan refleksi. Pada siklus I peserta didik yang tuntas setelah melaksanakan test sebesar $60 \%$, pada siklus II $80 \%$, dan pada siklus III $87 \%$. Hasil ini menunjukan bahwa model pembelajaran discovery learning dapat meningkatkan prestasi belajar peserta didik khususnya muatan pelajaran IPA Kelas VI di SDN Tepakyang.

Kata kunci: model discovery learning, prestasi belajar, IPA

Social, Humanities, and Education Studies (SHEs): Conference Series https://jurnal.uns.ac.id/shes

p-ISSN 2620-9284

e-ISSN 2620-9292 


\section{PENDAHULUAN}

Proses belajar mengajar diharapkan dapat memberikan pengalaman kepada peserta didik sebagai subjek belajar. Selain itu, pembelajaran diharapkan dapat memberikan bekal bagi peserta didik untuk hidup di masyarakat baik sikap, pengetahuan, dan keterampilan. Upaya untuk memperoleh pengalaman diperlukan adanya interaksi yang efektif baik antara guru dengan peserta didik, antara peserta didik dengan peserta didik, maupun antara peserta didik dengan lingkungan belajarnya untuk dapat mencapai tujuan pembelajaran. Guru berperan sebagai fasilitator yang bertugas untuk mendorong peserta didik aktif dalam upaya memperoleh pengalaman. Pembelajaran tidak hanya sebatas transfer of knowledge tetapi juga membutuhkan proses aktif peserta didik untuk membangun sendiri pengetahuannya.

IImu Pengetahuan Alam (IPA) sebagai salah satu muatan pelajaran yang mengantarkan peserta didik dalam proses perubahan perilaku sebagai hasil interaksi dengan lingkungannya untuk mencapai tujuan. Oleh karena itu diperlukan adanya partisipasi aktif peserta didik dalam pembelajaran sebagai upaya untuk memperoleh pengalaman. Konsep pendidikan dalam pembelajaran IPA yaitu pendekatan atau model pembelajaran harus memberi kemungkinan agar peserta didik dapat menunjukkan keaktifan penuh dalam belajar (active learning). Selain itu proses pendidikan yang diciptakan dari suatu Modelharus menciptakan suasana menyenangkan bagi peserta didik sehingga peserta didik dapat belajar secara nyaman dan gembira (joyfull learning).

Namun berdasarkan pengalaman peneliti di Kelas VI SD Negeri Tepakyang Kabupaten Kebumen Tahun Pelajaran 2020/2021 proses pembelajaran tidak berlangsung sebagaimana mestinya. Kegiatan pembelajaran hanya melibatkan peserta didik tertentu yang aktif sedangkan peserta didik yang lain kurang memperhatikan pelajaran. Kurangnya inovasi dalam pembelajaran, penggunaan model pembelajaran belum variatif menjadikan beberapa peserta didik terlihat bosan, hal tersebut terlihat ketika guru memberikan kesempatan bertanya tetapi tidak ada satu peserta didikpun yang bertanya. Hal tersebut menunjukkan rasa keingintahuan peserta didik yang masih rendah. Hal ini terjadi karena guru terkesan mendominasi pada pembelajaran (teacher center) dan akhirnya prestasi belajar belum optimal. Terbukti nilai Ulangan Harian pada muatan pelajaran IPA 10 peserta didik dari 15 peserta didik memperoleh nilai di bawah Kriteria Ketuntasan Minimal (KKM).

Winkel (2009) mengemukakan bahwa prestasi belajar merupakan perubahan dalam bidang kognitif, bidang sensorik-motorik, bidang dinamik-afektif, dan mengakibatkan manusis berubah dalam sikap dan tingkah lakunya. Maka prestasi belajar merupakan hasil maksimum yang dicapai oleh seseorang setelah melaksanakan usaha-usaha belajar. Jadi prestasi belajar adalah hasil pengukuran dari penilaian usaha belajar yang dinyatakan dalam bentuk simbol, huruf maupun kalimat yang menceritakan hasil yang sudah dicapai oleh setiap anak pada periode tertentu. Prestasi belajar merupakan hasil dari pengukuran terhadap peserta didik yang meliputi faktor kognitif, afektif dan psikomotor setelah mengikuti proses pembelajaran yang diukur dengan menggunakan instrumen tes yang relevan. Pembelajaran IPA diharapkan dapat membantu siswa untuk memahami fenomena-fenomena alam (Fitriyati, dkk, 2017). Pengujian teori yang ada di dalam IPA dapat dilakukan melalui proses pembelajaran. Proses pembelajaran yang berlangsung harus bisa membuat peserta didik mengerti mengenai teori IPA. Pembelajaran IPA yang memberikan kesempatan siswa untuk mengkonstruksi konsep sendiri, akan memberikan pengalaman langsung untuk menjelajahi dan memahami alam sekitar secara ilmiah. Pembelajaran IPA dengan memberikan pengalaman langsung dapat menumbuhkan cognitive thingking skill (keterampilan berpikir kognitif), psychomotor skills (keterampilan psikomotorik) dan social skills (keterampilan sosial). Dalam penelitian ini 
yang dimaksud IPA adalah pengetahuan yang berhubungan dengan cara mencari tahu mengenai suatu pengetahuan secara sistematis melalui suatu proses penemuan yang melibatkan aktivitas peserta didik.

Pembelajaran IPA pada penelitian ini menggunakan model pembelajaran discoveri learning atau model pembelajaran penyingkapan/penemuan. Syah (dalam Darmadi, 2017: 114-117) terdapat prosedur yang harus digunakan dalam mengaplikasikan model discovery learning yaitu (a) stimulation (pemberian rangsangan); (b) problem statement (identifikasi masalah); (c) data collection (pengumpulan data); (d) data processing (pengolahan data); (e) Verification (pembuktian); dan (f) generalization (menarik kesimpulan). Model pembelajaran discovery merupakan suatu model pengajaran yang menitikberatkan pada aktifitas peserta didik dalam belajar. Tiga ciri utama belajar menemukan yaitu: (1) mengeksplorasi dan memecahkan masalah untuk menciptakan, menggabungkan dan menggeneralisasi pengetahuan; (2) berpusat pada peserta didik; (3) kegiatan untuk menggabungkan pengetahuan baru dan pengetahuan yang sudah ada. Penerapan model pembelajaran discovery learning dalam muatan pelajaran IPA merupakan salah satu alternatif dalam upaya meningkatkan prestasi belajar IPA.

\section{METODE}

Penelitian ini adalah penelitian tindakan kelas (Classroom Action Research) dengan menerapkan model pembelajaran discovery learning. Arikunto (2013) menjelaskan bahwa satu siklus PTK terdiri dari empat langkah yaitu: (1) perencanaan, (2) pelaksanaan, (3) pengamatan, dan (3) refleksi. Penelitian tindakan kelas ini dilaksanakan dalam tiga siklus secara daring, dengan setiap siklus terdiri dari perencanaan, tindakan, observasi dan refleksi. Subjek penelitian ini adalah peserta didik kelas VI SDN Tepakyang yang berjumlah 15 peserta didik. Sumber data penelitian ini adalah peserta didik, observer dan peneliti. Teknik pengumpulan data menggunakan tes yang dilaksanakan pada akhir pembelajaran di setiap siklus untuk mengetahui prestasi belajar peserta didik yang dilaksanakan melalui google form. Nontes berupa lembar observasi untuk mengamati proses pembelajaran dengan syntak discovery learning selama proses pembelajaran berlangsung. Analisis data dilakukan untuk mengetahui sejauh mana hasil yang diperoleh dari data penelitian yang telah dilakukan pada setiap pertemuan. Penelitian ini menggunakan deskriptif kuantitatif. Deskriptif kuantitatif digunakan untuk mengolah data dari hasil tes. Data yang diperoleh dalam penelitian ini berupa hasil belajar peserta didik pada ranah kognitif (prestasi belajar).

\section{HASIL DAN PEMBAHASAN}

Upaya meningkatkan prestasi belajar IPA dengan menerapan model pembelajaran Discovery Learning pada Siklus I dilakukan dengan beberapa tahapan diantaranya perencanaan, tahap perencanaan ini ada beberapa hal perlu dipersiapkan yaitu menyusun perangkat pembelajaran, membuat rencana pelaksanaan pembelajaran daring dengan menerapkan langkah-langkah model pembelajaran discovery learning pada muatan pembelajaran IPA materi adaptasi tumbuhan teratai, mengkondisikan kelas, membuat link untuk pembelajaran daring, menyiapkan instrumen penilaian dan lembar observasi, serta pendokumentasian.

Tahap tindakan dengan pelaksanaan pembelajaran dengan muatan pembelajaran IPA tentang adaptasi tumbuhan. Pembelajaran dengan model discovery learning dilaksanakan mulai dari langkah pemberian rangsangan, identifikasi masalah, pengumpulan data, pengolahan data, pembuktian dan menarik kesimpulan. Berdasarkan pengamatan hasil evaluasi belajar pada muatan pelajaran IPA pada siklus I dapat dilihat pada tabel 1. 
Tabel 1. Prestasi Belajar Peserta Didik Siklus I

\begin{tabular}{|c|c|c|c|c|c|}
\hline No & Nilai (x) & frekuensi(f) & $f x$ & Presentase (\%) & Ket \\
\hline 1 & 50 & 1 & 50 & 6,7 & Belum Tuntas \\
\hline 2 & 60 & 5 & 300 & 33,3 & Belum Tuntas \\
\hline 3 & 70 & 4 & 280 & 26,7 & Tuntas \\
\hline 4 & 80 & 3 & 240 & 20,0 & Tuntas \\
\hline 5 & 90 & 2 & 180 & 13,3 & Tuntas \\
\hline \multicolumn{2}{|r|}{$\Sigma$} & 15 & 1.050 & $100 \%$ & \\
\hline \multicolumn{2}{|c|}{$<\mathrm{KKM}(70)$} & 6 & & $40 \%$ & Belum Tuntas \\
\hline \multicolumn{2}{|c|}{$\geq \mathrm{KKM}(70)$} & 9 & & $60 \%$ & Tuntas \\
\hline \multicolumn{2}{|c|}{ Nilai Rata-rata } & & & 71,0 & \\
\hline \multicolumn{2}{|c|}{ Nilai tertinggi } & & & 90 & \\
\hline \multicolumn{2}{|c|}{ Nilai terendah } & & & 50 & \\
\hline
\end{tabular}

Dari hasil di atas terlihat bahwa pada siklus I tingkat keberhasilan pada prestasi peserta didik mencapai 9 peserta didik yang artinya prestasi peserta didik yang masuk pada kategori tuntas ada $60 \%$ dari total peserta didik di kelas. Kriteria keberhasilan dari penelitian ini yaitu jika nilai $87 \%$ dari keseluruhan peserta didik telah mencapai Ktiteria Ketuntasan Minimal (KKM) yaitu sebesar 70. Setelah melakukan refleksi berdasarkan hasil prestasi peserta didik pada siklus I maka perlu diadakan perbaikan pembelajaran pada siklus berikutnya.

Siklus II membahas materi tentang adaptasi tumbuhan berdasarkan habitatnya, pembelajaran dengan model discovery learning dilaksanakan mulai dari langkah pemberian rangsangan, identifikasi masalah, pengumpulan data, pengolahan data, pembuktian dan menarik kesimpulan. Berdasarkan pengamatan hasil evaluasi belajar pada muatan pelajaran IPA pada siklus II dapat dilihat pada tabel 2.

Tabel 2. Prestasi Belajar Peserta Didik Siklus II

\begin{tabular}{|c|c|c|c|c|c|}
\hline No & Nilai (x) & frekuensi(f) & $f x$ & Presentase (\%) & Ket \\
\hline 1 & 60 & 3 & 180 & 20,0 & Belum Tuntas \\
\hline 2 & 70 & 5 & 350 & 33,3 & Belum Tuntas \\
\hline 3 & 80 & 4 & 320 & 26,7 & Belum Tuntas \\
\hline 4 & 90 & 3 & 270 & 20,0 & Tuntas \\
\hline \multicolumn{2}{|r|}{$\Sigma$} & 15 & 1.120 & $100 \%$ & \\
\hline \multicolumn{2}{|c|}{$<\mathrm{KKM}(70)$} & 3 & & $20 \%$ & Belum Tuntas \\
\hline \multicolumn{2}{|c|}{$\geq \mathrm{KKM}(70)$} & 12 & & $80 \%$ & Tuntas \\
\hline \multicolumn{2}{|c|}{ Nilai Rata-rata } & & & 75,0 & \\
\hline \multicolumn{2}{|c|}{ Nilai tertinggi } & & & 90 & \\
\hline \multicolumn{2}{|c|}{ Nilai terendah } & & & 60 & \\
\hline
\end{tabular}

Berdasarkan tabel 2. tentang prestasi belajar peserta didik pada siklus II diketahui bahwa yang memenuhi Kriteria Ketuntasan Minimal (KKM) yaitu 70 sebanyak 12 peserta didik atau sebesar $80 \%$ sedangkan yang mendapat nilai di bawah KKM sebanyak 3 peserta didik atau $20 \%$. Perolehan nilai rata-rata kelas sebesar 75 dengan nilai tertinggi 90 dan nilai terendah 60 . Berdasarkan observasi pada prestasi peserta didik, persentase peserta didik yang mencapai KKM belum mencapai indikator kinerja yang sudah ditentukan yaitu sebesar $87 \%$. Dari hasil prestasi peserta didik pada siklus II maka perlu diadakan perbaikan pembelajaran pada siklus berikutnya.

Pada siklus III materi yang dibahas tentang adaptasi tumbuhan berdasarkan habitatnya, pembelajaran dengan model discovery learning dilaksanakan mulai dari langkah pemberian rangsangan, identifikasi masalah, pengumpulan data, pengolahan 
data, pembuktian dan menarik kesimpulan. Berdasarkan pengamatan hasil evaluasi belajar pada muatan pelajaran IPA pada siklus III dapat dilihat pada tabel 3.

Tabel 3. Prestasi Belajar Peserta Didik Siklus III

\begin{tabular}{|c|c|c|c|c|c|}
\hline No & Nilai (x) & frekuensi(f) & fx & Presentase (\%) & Ket \\
\hline 1 & 60 & 2 & 140 & 13,3 & Belum Tuntas \\
\hline 2 & 70 & 7 & 490 & 46,7 & Tuntas \\
\hline 3 & 80 & 5 & 400 & 33,3 & Tuntas \\
\hline 4 & 90 & 1 & 90 & 6,7 & Tuntas \\
\hline \multicolumn{2}{|r|}{$\Sigma$} & 15 & 1.120 & $100 \%$ & \\
\hline \multicolumn{2}{|c|}{$<\operatorname{KKM}(70)$} & 2 & & $13 \%$ & Belum Tuntas \\
\hline \multicolumn{2}{|c|}{$\geq \mathrm{KKM}(70)$} & 13 & & $87 \%$ & Tuntas \\
\hline \multicolumn{2}{|c|}{ Nilai Rata-rata } & & & 75,0 & \\
\hline \multicolumn{2}{|c|}{ Nilai tertinggi } & & & 90 & \\
\hline \multicolumn{2}{|c|}{ Nilai terendah } & & & 60 & \\
\hline
\end{tabular}

Berdasarkan tabel 3 tentang prestasi belajar peserta didik pada siklus III diketahui bahwa yang memenuhi Kriteria Ketuntasan Minimal (KKM) yaitu 70 sebanyak 13 peserta didik atau sebesar $87 \%$ sedangkan yang mendapat nilai di bawah KKM sebanyak 2 peserta didik atau 13\%. Perolehan nilai rata-rata kelas sebesar 75 dengan nilai tertinggi 90 dan nilai terendah 60 . Berdasarkan observasi pada prestasi peserta didik, persentase peserta didik yang mencapai KKM sudah mencapai indikator kinerja yang ditetapkan yaitu $87 \%$.

Prestasi belajar peserta didik dari siklus I sampai siklus III mengalami perubahan. Untuk analisis prestasi belajar tersebut dapat dilihat pada tabel 4 .

Tabel 4. Analisis Prestasi Belajar Peserta Didik pada Siklus I-III

\begin{tabular}{llcl}
\hline No & Tindakan & Rata-rata ketuntasan prestasi belajar (\%) & Keterangan \\
\hline 1 & Siklus I & 60 & \\
2 & Siklus II & 80 & Meningkat $20 \%$ \\
3 & Siklus III & 87 & Meningkat $7 \%$ \\
\hline
\end{tabular}

Berdasarkan tabel 4 dapat diketahui bahwa prestasi belajar peserta didik pada siklus I sampai III selalu mengalami perubahan. Pencapaian prestasi belajar peserta didik yang mencapai $\geq \mathrm{KKM}$ pada siklus I ke siklus II mengalami kenaikan sebesar $20 \%$, sedangkan pada siklus II ke siklus III mengalami kenaikan sebesar $7 \%$. Pencapaian prestasi belajar dari setiap siklus tersebut merupakan perubahan ke arah pencapaian yang lebih baik. Sehingga dari siklus I sampai siklus III mengalami peningkatan sebesar $27 \%$. Untuk lebih jelasnya mengenai analisis prestasi belajar peserta didik tersebut dapat dilihat pada gambar 1.

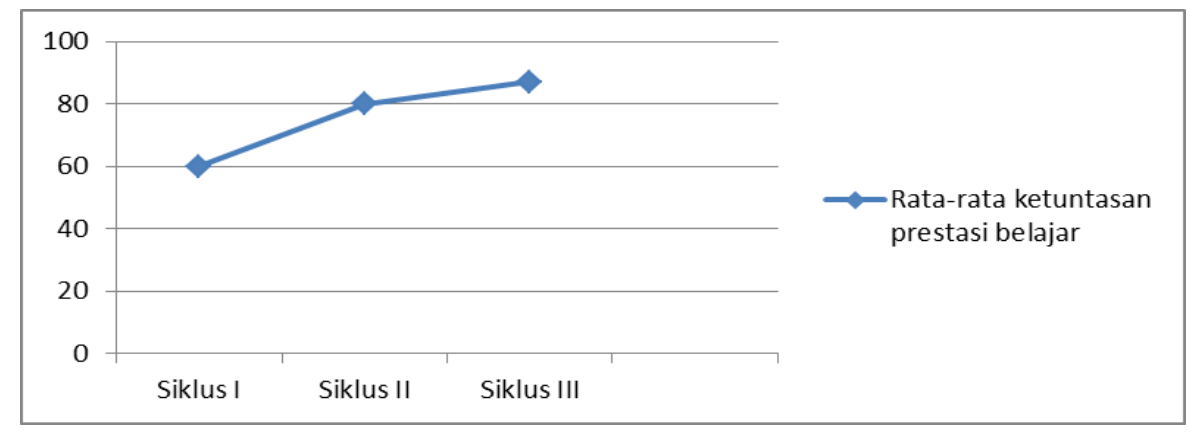

Gambar 1. Diagram Analisis Prestasi Belajar pada Siklus I-III 
Berdasarkan pendapat Hanifah dan Wasitohadi (2017) bahwa discovery learning merupakan model pembelajaran yang mengajak siswa belajar aktif menemukan sendiri pengetahuannya, hal itu akan membuat siswa merasa tertantang dan tertarik untuk mengidentifikasi permasalahan dengan suatu percobaan sehingga siswa akan merasa tertarik untuk memahami materi dan menguasai materi pembelajaran. Dalam penelitian ini dapat dipastikan bahwa model pembelajaran discovery learning dapat meningkatkan prestasi belajar peserta didik pada muatan pelajaran IPA Kelas VI SDN Tepakyang. Peserta didik dapat menganalisis tentang adaptasi tumbuhan dengan melakukan pengamatan secara langsung pada tanaman di sekitar lingkungan sehingga pengetahuan yang diperoleh dengan proses yang bermakna.

\section{SIMPULAN}

Berdasarkan hasil penelitian yang telah peneliti laksanakan tentang Peningkatan Prestasi Belajar IPA Melalui Penerapan Model Discovery Learning pada Peserta Didik Kelas VI SDN Tepakyang, dapat ditarik kesimpulan bahwa Penerapan model discovery learning dapat meningkatkan prestasi belajar IPA peserta didik tentang adaptasi tumbuhan kelas VI SDN Tepakyang pada tahun 2020/2021 dengan rata-rata ketuntasan prestasi belajar siklus I sebesar $60 \%$, siklus II sebesar $80 \%$ dan pada siklus III $87 \%$. Peningkatan rata-rata prestasi belajar dari siklus I sampai siklus III sebesar $27 \%$. Peneliti menyarankan pada guru SD kelas VI khususnya lam pembelajaran IPA tentang adaptasi tumbuhan untuk menerapkan model discovery learning, karena dengan model ini peserta didik terlibat lebih aktif dalam pembelajaran dan dilatih untuk menemukan dan mengolah data dari berbagai sumber belajar. Pihak sekolah disarankan menyediakan sarana dan prasarana yang mendukung terlaksananya pembelajaran yang lebih bermakna dengan model discovery learning.

\section{DAFTAR PUSTAKA}

Arikunto, S. (2013). Prosedur Penelitian suatu Pendekatan Praktik. Jakarta: PT Rineka Cipta.

Cintia, NI, dkk. (2018). Penerapan Model Pembelajaran Discovery Learning untuk Meningkatkan Kemampuan Berpikir Kreatif dan Hasil Belajar Siswa. PERSPEKTIF IImu Pendidikan - Vol. 32.

Darmadi. (2017). Pengembangan Model dan Metode Pembelajaran dalam Dinamika Belajar Siswa. Yogyakarta: CV. Budi Utama.

Fitriyati, I, dkk. (2017). Pengembangan Perangkat Pembelajaran IPA untuk Meningkatkan Kemampuan Berpikir Tinggi dan Penalaran IImiah Siswa Sekolah Menengah Pertama. Jurnal Pembelajaran Sains, 4(1). 27-34.

Winkel, W.S. (2009). Psikologi Pengajaran. Jakarta: PT. Media Abadi 